\title{
The role of microorganisms in mobilization and fixation of phosphorus in sediments
}

\author{
René Gächter ${ }^{1} \&$ Joseph S. Meyer ${ }^{2}$ \\ ${ }^{1}$ Institute of Aquatic Sciences (EAWAG), Swiss Federal Institute of Technology (ETH), CH-6047 \\ Kastanienbaum, Switzerland; ${ }^{2}$ Department of Fisheries, Humboldt State University, Arcata, CA 95521 , \\ $U S A$
}

Key words: bacteria, phosphorus, phosphorus cycling in lakes, sediments

\begin{abstract}
Cycling of phosphorus (P) at the sediment/water interface is generally considered to be an abiotic process. Sediment bacteria are assumed to play only an indirect role by accelerating the transfer of electron from electron donors to electron acceptors, thus providing the necessary conditions for redoxand $\mathrm{pH}$-dependent, abiotic sorption/desorption or precipitation/dissolution reactions.

Results summarized in this review suggest that

(1) in eutrophic lakes, sediment bacteria contain as much $\mathbf{P}$ as settles with organic detritus during one year,

(2) in oligotrophic lakes, $\mathbf{P}$ incorporated in benthic bacterial biomass may exceed the yearly deposition of bioavailable $P$ several times,

(3) storage and release of $\mathbf{P}$ by sediment bacteria are redox-dependent processes,

(4) an appreciable amount of $\mathrm{P}$ buried in the sediment is associated with the organic fraction,

(5) sediment bacteria not only regenerate $\mathrm{PO}_{4}$, they also contribute to the production of refractory, organic $\mathbf{P}$ compounds, and

(6) in oligotrophic lakes, a larger fraction of the $\mathbf{P}$ settled with organic detritus is converted to refractory organic compounds by benthic microorganisms than in eutrophic lakes.
\end{abstract}

From this we conclude that benthic bacteria do more than just mineralize organic $P$ compounds. Especially in oligotrophic lakes, they also may regulate the flux of $\mathrm{P}$ across the sediment/water interface and contribute to its terminal burial by the production of refractory organic $\mathrm{P}$ compounds.

\section{Introduction}

While, scattered information indicates that bacteria might directly be involved in the control of $P$ flux across the sediment/water interface, an overwhelming number of case studies have described $\mathbf{P}$ cycling at the sediment/water interface ignoring bacteria or by considering them only as incorporeal catalyzers of mineralization as sketched in Fig. 1a.
This paper, critically reviews, reevaluates and analyzes reported results on the contribution of bacteria to the phosphorus (P) cycling across the sediment/water interface. It emphasizes the state of knowledge, defines gaps, reassesses research strategies, and addresses the following two questions:

1. Under what environmental conditions do bacteria need to be considered as organisms in 
order to understand $\mathbf{P}$ cycling across the sediment/water interface, and under what conditions can they be neglected?

2 What environmental conditions favour the production of refractory organic $\mathbf{P}$ compounds, and what conditions favour regeneration and recycling of bioavailable $P$ ?

\section{Classical view of phosphorus cycling in lakes}

According to the classical view of $\mathbf{P}$ cycling in lakes (Fig. 1a), phosphate $\left(\mathrm{PO}_{4}\right)$ flushed into a lake by its tributaries or released from the sediments is taken up from the water by living and non-living suspended particles and lost to the lake bottom in proportion to the settling velocities of the particles. In the sediment, organic $\mathrm{P}$ is liberated as soluble $\mathrm{PO}_{4}$ to solution during decomposition by bacteria, or it becomes buried as refractory organic $\mathbf{P}$. The liberated $\mathbf{P O}_{4}$ may be adsorbed to inorganic surfaces, complexed by refractory organic materials, or precipitated as apatite or vivianite. Part of it may remain in solution or be recycled into the overlying water. In many cases, the flux of $\mathrm{PO}_{4}$ from the sediment to the water is largely controlled by the prevailing redox conditions at the sediment/water interface. An oxidized sediment surface often prevents or strongly diminishes release of $\mathrm{PO}_{4}$ from the sediment to the water. It forms an efficient trap for dissolved iron $(\mathrm{Fe})$, manganese $(\mathrm{Mn})$ and $\mathrm{PO}_{4}$ moving the interstitial water from reduced sediments to the oxic surface. When the hypolimnion and, hence, the sediment surface become anoxic, this barrier disappears and release rates of $\mathrm{Fe}$, $\mathrm{Mn}$ and $\mathrm{PO}_{4}$ often increase markedly, indicating reduction of ferric hydroxide complexes and subsequent release of ferric iron and adsorbed $\mathrm{PO}_{4}$ (Mortimer, 1941, 1942, 1971; Einsele, 1936; Einsele \& Vetter, 1938). In lakes with too low a Fe:P ratio or with too high a $\mathrm{pH}$, release and binding of inorganic $P$ cannot be controlled exclusively by iron. Boström et al. (1982) discussed additional chemical, biological and physical mechanisms (e.g., sorption of $\mathbf{P}$ to clay minerals and humic substances, bacterial activity, bioturbation by benthic organisms, mobilization of $\mathrm{P}$ by rooted macrophytes, wind-induced turbulence in the sediment overlying water, resuspension, gas ebullition and temperature) controlling the cycling of $\mathbf{P}$ at the sediment/water interface.

\section{Can bacteria be neglected as a transient $P$ pool?}

In the scenario described above, bacteria are treated only as 'catalysts' that accelerate solubilization of $\mathrm{PO}_{4}$, by oxidation of organic detritus and reduction of various oxidants. Consuming $\mathrm{O}_{2}, \mathrm{NO}_{3}^{-}$and $\mathrm{SO}_{4}^{2-}$, they provide the necessary conditions for abiotic or biotic reduction of ferric iron $\left(\mathrm{Fe}^{3+}\right)$, subsequent release of $\mathrm{PO}_{4}$ and precipitation of iron sulfide ( $\mathrm{FeS})$. The concentration of dissolved $\mathrm{PO}_{4}$ in the interstitial water is assumed to be controlled by mineralization, by abiotic physical/chemical equilibria of precipitation/ dissolution or sorption/desorption, and by diffusion.

By definition, catalysts are neither produced nor consumed during a chemical reaction, and their composition and pool size are constant. Thus, it is assumed that the amount of $\mathbf{P}$ bound to bacteria does not vary (i.e., uptake is always compensated by release, independent of varying environmental conditions). As a consequence, uptake and release of $\mathrm{PO}_{4}$ by bacteria and, hence, their potential role in accelerating or retarding $P$ exchange across the sediment/water interface, often is disregarded or considered to be negligible in comparison to mineralization rate and chemical equilibria.

Bacteria are not, however, only incorporeal sites of enzyme production (Fig. 1b). More likely, as other organisms, they depend on $P$ as a nutrient; hence, they are able to take it up from the organic substrate or from the water. Net release seems to be controlled by their demand for P. For example, Gächter \& Mares (1985) and others (cited in their paper) observed that during decomposition of settling detritus, no $\mathrm{PO}_{4}$ was released. They suggested that heterotrophic organisms colonizing and decomposing $\mathrm{P}$-deficient settling organic material may be a sink, rather than a source, 
Traditional model

organic

seston
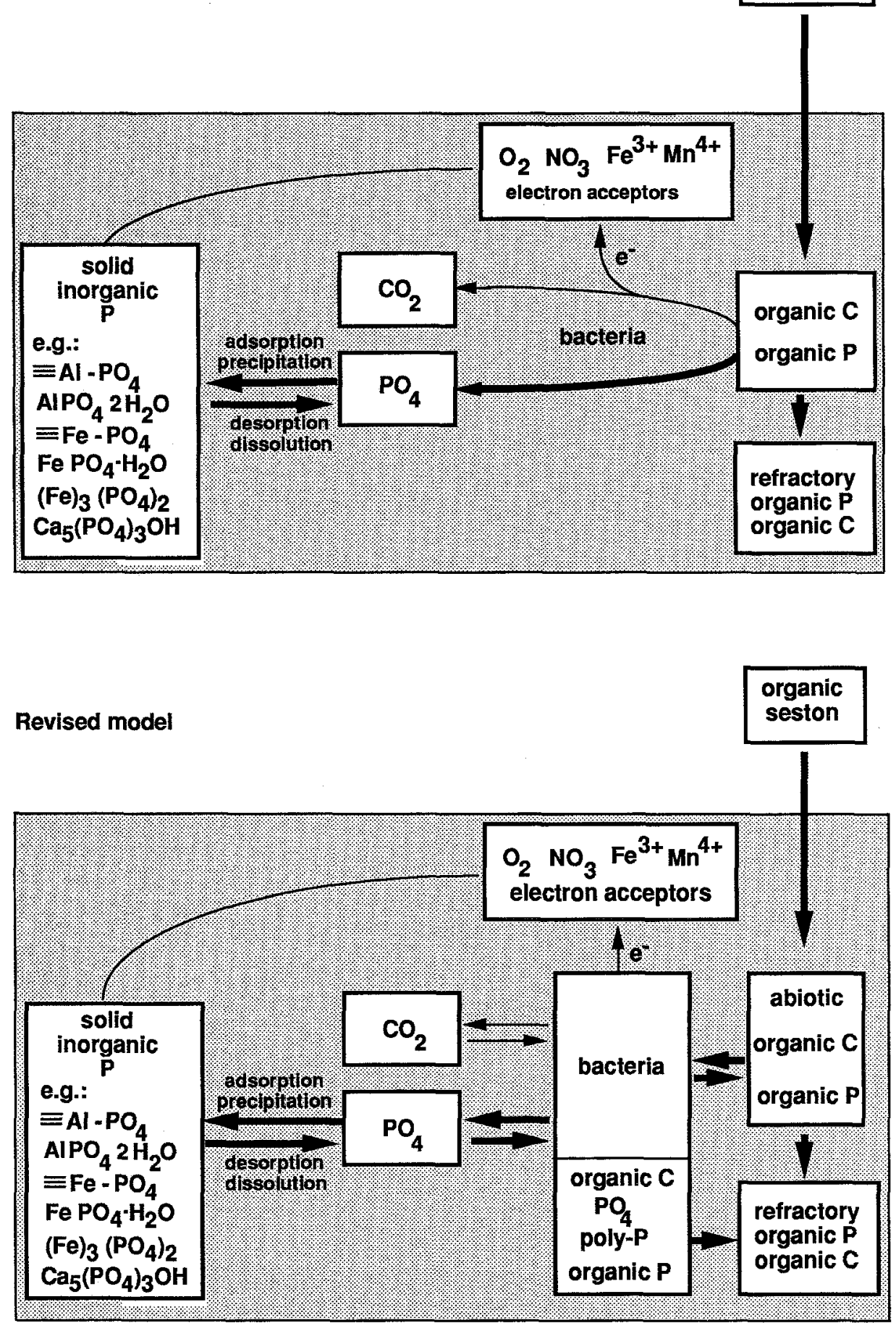

Fig. 1. Classical model (Fig. 1a) and a more conceptual model (Fig. 1b) of bacterial constribution to nutrient cycling. 
for $\mathrm{PO}_{4}$. Stöckli (1985) showed experimentally that microorganisms isolated from lakewater did not release but rather took up $\mathrm{PO}_{4}$ while decomposing dissolved organic matter produced by Chlamydomonas rheinhardii; half of the organic $\mathbf{P}$ excreted by bacteria was unavailable to algae. According to Jewell \& McCarty (1968), regeneration of $\mathbf{P}$ from decaying algae with low $\mathbf{P}$ content can be subdivided into three phases: In the first phase, soluble reactive $\mathrm{P}$ (SRP) is taken up by the algae or by their decomposers; in the second phase, the apparent nutrient regeneration is zero; and finally, in the third phase, active regeneration of $\mathbf{P}$ takes place. When this nutrient regeneration ceases, some of the initial $\mathbf{P}$ remains in the particulate refractory organic material.

Many bacteria are able to store $\mathrm{PO}_{4}$ in the form of polyphosphates (poly-P), if $\mathrm{PO}_{4}$ is available in excess (Kulaev, 1979). For example, poly-P can constitute up to about $20 \%$ of the dry weight in Acinetobacter spp. (Deinema et al., 1980). This phenomenon has been studied extensively because it offers a possibility to remove $\mathrm{PO}_{4}$ from wastewater (see e.g., Van Groenestijn, 1988). These bacteria are also common in aquifers, surface waters and soils. According to Wentzel et al. (1986), they are not able to gain energy by fermentation of glucose under anaerobic conditions. However, if sufficient organic carbon and $\mathrm{PO}_{4}$ are available, under aerobic conditions these organisms polymerize excess $\mathrm{PO}_{4}$ and store energy in the resulting energy rich poly-P. Under subsequent anaerobic conditions, poly-P can be hydrolyzed and the resulting high-energy $\mathrm{PO}_{4}$ can be used to synthesize ATP from ADP. In this process, inorganic $\mathbf{P}$ is released intracellularly and eventually diffuses along the concentration gradient into the surrounding medium.

Gächter et al. (1988) observed that bacteria isolated from eutrophic lakes sediments responded in a similar way as sewage sludge bacteria, when exposed to alternating aerobic/ anaerobic conditions. Thus, there is no reason to assume a priori that the size of the $\mathrm{P}$ pool in sediment bacteria would be constant under changing environmental conditions (e.g., changing redox potential, or changing supply and com- position of organic material). However, it remains to be seen whether variation in their pool size could significantly affect $\mathrm{PO}_{4}$ concentrations in the pore water and, hence, the exchange of $\mathrm{PO}_{4}$ across the sediment/water interface.

From a thermodynamic perspective, all organic material is eventually decomposable if redox conditions are favourable. However, concentration profiles of organic material in sediments suggest that part of the settled organic material is decomposed so slowly that it can be considered to be refractory on a time scale of some hundred years. As bacteria decompose settled organic material, bacterial biomass is produced in the sediment. It seems unlikely that all bacterial biomass produced would be easily degradable. Hence, bacterial production may eventually increase the amount of refractory debris that becomes buried in the sediment.

Recruitment of benthic colonies of cyanobacteria to the water column is another biological mechanism that might increase the flux of $P$ from sediments to lake water, as suggested by Boström (1985) for Microcystis and observed by Osgood (1988) for Aphanizomenon and by Wolf (1986) for Oscillatoria.

In summary, bacteria at the sediment/water interface may perform the following functions:

- catalyze the mineralization of organic P;

- take up and transiently store $P$ in their biomass;

- release $\mathbf{P}$ if redox conditions are not favourable;

- release $\mathbf{P}$ when they die and thus, themselves, become decomposed;

- convert bioavailable SRP into dissolved or particulate refractory $P$; and

- transfer $P$ in particulate form from the sediment to the water column or vice versa.

\section{Estimation of $P$ bound transiently by sediment bacteria}

\section{The P/biovolume ratio in bacteria}

In addition to bacterial $P$, sediments contain many other sorts of detrital organic and inorganic $\mathbf{P}$ compounds. Since most bacteria are closely 
associated with such abiotic solid phases, determination of the bacterial $\mathbf{P}$ pool size requires a quantitative physical separation of bacteria from other solids. To our knowledge, no such technique is currently available. Hence, $\mathrm{P}$ bound to bacteria cannot be measured directly. Indirect estimations require information about bacterial biovolume and the $\mathbf{P}$ content of bacterial cells.

The biovolume can be obtained from direct microscopic inspection of stained bacteria, yielding number of cells and average cell volume.

Determination of bacterial $\mathbf{P}$ content requires a bacterial culture that contains no particulate phosphorus (PP) other than bacteria. In addition, environmental conditions of the culture should mimic those of the investigated sediment as closely as possible. Cultivation of bacteria in interstitial water might be a suitable method, especially if a technique could be found to dissolve (e.g., by blending, grinding or ultrasonifying) at least part of the decomposable particulate organic material into the interstitial water before separating interstitial water from the sediment. Formation of iron oxyhydroxides sorbing $P$ could be prevented by keeping the culture anoxic or by adding a chelator, that is not easily biologically degradable (e.g. EDTA).

As an alternative, Gächter et al. (1988) sampled bacteria grown in a benthic chamber in an- oxic water overlying the sediment of eutrophic Lake Sempach; that water contained no settling detritus and no particulate $\mathrm{Fe}$. Assuming that all PP was incorporated in bacteria, they estimated that bacterial biomass contained $15 \mu \mathrm{g} \mathrm{P} \mathrm{mm}$ of cell volume. This value lies only slightly above the range of 3 to $12 \mu \mathrm{g} \mathrm{Pm}^{-3}$ that Shuter (1978) and Vadstein et al. (1988) reported as a minimum cell quota of P. Despite the large variability of the results gathered in Table 1, we estimate that bacteria not limited by $\mathbf{P}$ might accumulate about $11 \mu \mathrm{g} \mathrm{mm}^{-3}$, even under anoxic conditions. In sediments where bacteria accumulate poly-P (e.g., Uhlmann \& Bauer, 1988), $11 \mu \mathrm{g} \mathrm{mm}^{-3}$ likely is a conservative estimate for the bacterial $\mathrm{P}$ content.

\section{The $C / P$ ratio in bacteria}

The particulate organic carbon (POC): bacterial volume ratio is affected by nutritional status and community structure (Bratbak \& Dundas, 1984). According to Riemann \& Bell (1990), values vary from $0.12-0.58 \mathrm{mg}$ POC $\mathrm{mm}^{-3}$. If we accept

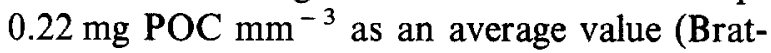
bak, 1985), assume that POC is $50 \%$ of the dry weight of the particulate organic matter and add some weight for inorganic salts, then the ratio of dry weight/biovolume must be close to $0.5 \mathrm{mg}$ $\mathrm{mm}^{-3}$. Bornsheim et al. (1990) report a dry

Table 1. Estimated P content of microbial biomass reported in literature. ${ }^{1)}$ Converted from $\% \mathrm{P}$ of dry weight (DW), assuming a DW/biovolume ratio of $0.5 \mathrm{~g} \mathrm{~m}^{-3}$ (s. page 8 ).

\begin{tabular}{lcc}
\hline Microbes & $\begin{array}{l}\mathrm{P} \text { content } \\
\left(\mu \mathrm{g} \mathrm{P} \mathrm{mm}^{-3}\right)\end{array}$ & Reference \\
\hline Mixed hypolimnic bacteria & 15 & Gächter et al. $(1988)$ \\
Mixed limnetic bacteia & $6-17$ & Vadstein et al. $(1988)$ \\
Acinetobacter calcoaceticus & $16-33^{1)}$ & Hoffmeister et al. $(1990)$ \\
Acinetobacter wolffi & $32-37^{1)}$ & Hoffmeister et al. $(1990)$ \\
Sewage bacteria & $4-42^{1)}$ & Kämpfer et al. $(1990)$ \\
Planktonic bacteria & 13 & Borsheim et al. $(1990)$ \\
& & \\
Minimum cell quota & & \\
Bacillus subtilis & 12 & Shuter (1978) \\
Pseudomonas aeruginosa & 7 & Shuter (1978) \\
Corynebacterium bovis & 8 & Shuter (1978) \\
Nitrosomonas europea & 4 & Shuter (1978) \\
Escherichia coli & 6 & Shuter (1978) \\
\hline
\end{tabular}


weight/biovolume ratio of $0.6 \mathrm{mg} \mathrm{mm}^{-3}$. Hence, this ratio is much larger for bacteria than for phytoplankton, where often a ratio of $0.2 \mathrm{mg} \mathrm{mm}^{-3}$ is reported (Vollenweider, 1974).

The C:P ratio of bacteria is affected by the redox condition and the C:P ratio of the substrate. Fenchel \& Blackburn (1979) and Gächter et al. (1988) reported C:P (weight) ratios for bacteria of 18.4 and 14.9, respectively. Vadstein et al. (1988) observed values varying between 3 and 29, with a median value of 11 . Combination of the widely accepted conversion factor of $220 \mu \mathrm{g} \mathrm{C}$ $\mathrm{mm}^{-3}$ (Bratbak, 1985) and a assumed average of C: $P$ ratio of 20 yields an average $P$ content of $11 \mu \mathrm{g} \mathrm{mm}^{-3}$ cell volume. This value lies at the lower end of the values gathered for bacteria not limited by $\mathrm{P}$ (Table 1 ), indicating that for bacteria not limited by $\mathbf{P}$, the $C: P$ ratio might even be $<20$. Definitely, the C:P ratio of bacteria is lower than the C:P ratio of settling seston which was reported to vary between 40 in eutrophic and 200 in oligotrophic lakes (Gächter et al., 1985).

\section{$P$ in sediment bacteria of lakes of different trophic states}

The number of bacteria generally increases about 3 to 5 orders of magnitude from the water to the sediment surface and then decreases rapidly

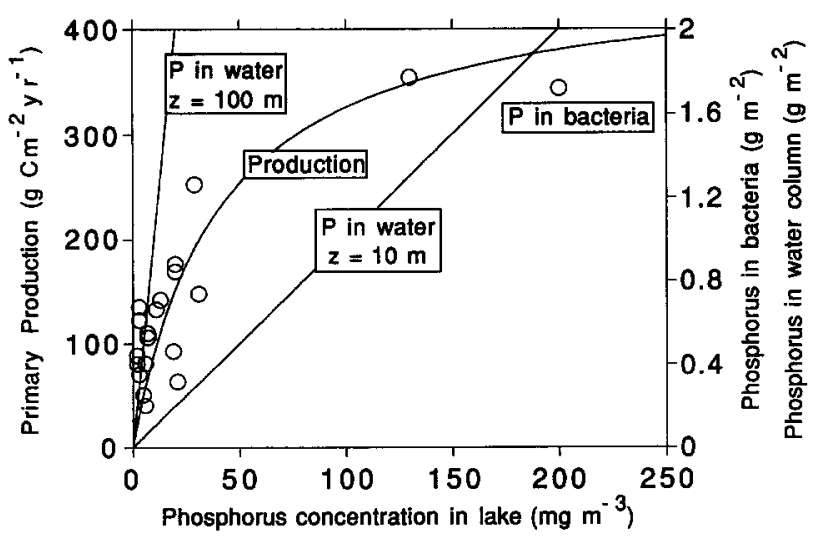

Fig. 2. Areal primary production (curve), benthic bacterial $\mathbf{P}$ content (circles) and areal $P$ content of the water column for average depths of 10 and $100 \mathrm{~m}$ (dashed lines) as a function of $\mathbf{P}$ concentration at spring overturn. Primary production $=456[P] /([P]+40)$ (Fricker, 1980); data for P content of benthic bacteria from Table 2 . within the sediment at greater depth. It also seems to vary horizontally over the lake basin, with higher numbers in the littoral zone covered by macrophytes and lower numbers in profundal sediments (Wetzel, 1983).

Figure 2 shows the relationship between yearly primary production rate (Prod) and a lake's $P$ concentration at spring overturn, as suggested by Fricker (1980). It also includes data on P fixed in benthic bacteria $\left(P_{\text {bact }}\right)$ (derived from Table 2 ) and on the $\mathbf{P}$ content of lakes, both related to the lakes' $\mathbf{P}$ concentrations. Comparison of the two axes for Prod and $P_{\text {bact }}$ suggests, as a first approximation a linear relationship between average benthic bacterial $\mathrm{P}$ content and primary production:

$$
\begin{aligned}
& \mathrm{P}_{\text {bact }}=k \cdot \text { Prod. } \\
& \text { with } \\
& k=0.005 \mathrm{yr} \mathrm{gP} / \mathrm{gC}
\end{aligned}
$$

Applying a C:P ratio of 20 , equation 1 suggests that organic $\mathrm{C}$ incorporated in benthic bacteria is equivalent to about $10 \%$ of the yearly primary production. Since a large fraction (normally $>80 \%$ ) of $\mathrm{C}$ assimilated by primary production is recycled in the water column and since part of the organic material reaching the sediment surface is refractory, only about $10 \%$ of the assimilated organic $\mathrm{C}$ might be mineralized in the sediment. Hence, the amount of organic $\mathrm{C}$ fixed in the benthic bacterial biomass is approximately equal to the amount of organic $\mathrm{C}$ that it dissimilates per year. This high ratio between standing crop of bacterial $\mathrm{C}$ and metabolized organic $\mathrm{C}$ suggests a very low metabolic activity of benthic bacteria. This conclusion is supported by Boström \& Törnblom (1990), who showed that at low temperatures average bacterial doubling times were as high as 2000-3000 days in marine sediments and higher than 1000 days in the sediment of the highly eutrophic Lake Vallentunasjön. Such low average growth rates indicate that a large fraction of sediment bacteria might be in a 'dormant' stage, not growing at all.

At steady state, bacterial production (BP), par- 
Table 2. Estimated biomass and $P$ content of benthic bacteia in various lakes. $B M=$ biomass, $B V=$ biovolume, $C N=$ cell number, $\mathrm{DW}=$ dry weight, $\mathrm{POC}=$ particulate organic carbon, $\mathrm{WW}=$ wet weight.

\begin{tabular}{|c|c|c|c|c|c|}
\hline Lake & $\begin{array}{l}\text { Bacterial } \\
\text { numbers } \\
\left(10^{6} \text { cells } \mathrm{g}^{-1}\right)\end{array}$ & $\begin{array}{l}\text { Biomass } \\
\left(\mathrm{g} \mathrm{C} \mathrm{m}^{-2}\right)\end{array}$ & 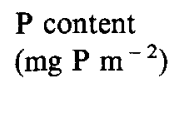 & $\begin{array}{l}\text { P conc. } \\
\left(\mu \text { g P liter }^{-1}\right)\end{array}$ & $\begin{array}{l}\text { Sediment } \\
\text { layer }(\mathrm{cm})\end{array}$ \\
\hline Beloe (Kosino) & $2326^{a}$ & $12.8-25.6^{\mathrm{b}}$ & $640-1280^{c}$ & & $0-5$ \\
\hline B. Medvezh'e & $1905^{a}$ & $10.5-21.0^{\mathrm{b}}$ & $525-1050^{c}$ & & $0-5$ \\
\hline Chernoe (Kosino) & $1285^{a}$ & $7.1-14.1^{\mathrm{b}}$ & $355-705^{c}$ & & $0-5$ \\
\hline M. Medvezh'e & $1624^{\mathrm{a}}$ & $8.9-17.9^{b}$ & $445-875^{\mathrm{c}}$ & & $0-5$ \\
\hline Sviatoe (Kosino) & $922^{\mathrm{a}}$ & $5.1-10.1^{\mathrm{b}}$ & $255-505^{c}$ & & $0-5$ \\
\hline Krugloe & $1110^{\mathrm{a}}$ & $6.1-12.2^{\mathrm{b}}$ & $305-610^{c}$ & & $0-5$ \\
\hline Gab (Karelian region) & $1883^{\mathrm{a}}$ & $10.4-20.7^{b}$ & $520-1035^{c}$ & & $0-5$ \\
\hline Lake Sempach $^{\mathrm{d}}$ & & 25.5 & 1770 & 130 & $0-5$ \\
\hline Mirror Lake & & 4.0 & $200^{\mathrm{c}}$ & 6 & $0-10$ \\
\hline Vallentunasjön ${ }^{\mathrm{f}}$ & & 34.0 & $1720^{\circ}$ & 200 & $0-10$ \\
\hline Lake Luzern ${ }^{\mathrm{g}}$ & & $7.5-25.4^{\mathrm{i}}$ & $375-1270^{\mathrm{c}}$ & 20 & $0-5$ \\
\hline Wastwater ${ }^{\mathrm{h}}$ & & $6.8-9.3^{1}$ & $340-465^{\mathrm{c}}$ & 2 & $0-10^{k}$ \\
\hline Ennerdale $^{\mathrm{h}}$ & & $7.6-10.2^{1}$ & $380-510^{c}$ & 2 & $0-10^{\mathrm{k}}$ \\
\hline Buttermere $^{\mathrm{h}}$ & & $4.2-5.9^{1}$ & $210-295^{c}$ & 5 & $0-10^{\mathrm{k}}$ \\
\hline Crummock $^{\mathrm{k}}$ & & $5.1-9.0^{1}$ & $255-450^{\mathrm{c}}$ & 3 & $0-10^{k}$ \\
\hline Coniston $^{\mathrm{h}}$ & & $10.2-16.9^{l}$ & $510-845^{c}$ & 3 & $0-10^{\mathrm{k}}$ \\
\hline Thirimere $^{\mathrm{h}}$ & & $11.0-13.5^{1}$ & $550-675^{\mathrm{c}}$ & 3 & $0-10^{\mathrm{k}}$ \\
\hline Windermere $(\mathrm{N})^{\mathrm{h}}$ & & $12.7-15.2^{1}$ & $635-785^{c}$ & 13 & $0-10^{\mathrm{k}}$ \\
\hline Ullswater $^{\mathrm{h}}$ & & $7.7-15.7^{1}$ & $330-770^{c}$ & 7 & $0-10^{\mathrm{k}}$ \\
\hline Derwentwater ${ }^{h}$ & & $6.8-8.5^{1}$ & $385-425^{c}$ & 6 & $0-10^{\mathrm{k}}$ \\
\hline Bassenthwaite ${ }^{\text {h }}$ & & $5.9-6.8^{1}$ & $295-340^{\mathrm{c}}$ & 21 & $0-10^{k}$ \\
\hline Windermere $(S)^{\mathrm{h}}$ & & $9.3-24.5^{1}$ & $465-1225^{c}$ & 20 & $0-10^{k}$ \\
\hline Loweswater ${ }^{h}$ & & $10.2-11.0^{1}$ & $510-550^{c}$ & 7 & $0-10^{k}$ \\
\hline Rydal Water ${ }^{\mathbf{b}}$ & & $13.1-13.5^{1}$ & $655-675^{c}$ & 11 & $0-10^{\mathrm{k}}$ \\
\hline Grasmere $^{\mathrm{h}}$ & & $6.8-11.8^{1}$ & $340-590^{c}$ & 19 & $0-10^{k}$ \\
\hline Esthwaite Water ${ }^{h}$ & & $11.8-17.8^{1}$ & $590-890^{c}$ & 31 & $0-10^{\mathrm{k}}$ \\
\hline Blelham Tarn ${ }^{\mathrm{h}}$ & & $16.1-34.3^{1}$ & $805-1720^{c}$ & 29 & $0-10^{\mathrm{k}}$ \\
\hline
\end{tabular}

a Wetzel (1983: 595).

${ }^{b} \mathrm{BM}=\left[\mathrm{CN} \mathrm{g}{ }^{-1} \mathrm{WW}\right] \cdot\left[1.05 \mathrm{~g} \mathrm{WW} \mathrm{cm}^{-3}\right] \cdot\left[5.10^{4} \mathrm{~cm}^{3} \mathrm{~m}^{-2}\right] \cdot\left[0.5\right.$ to $\left.1 \mu \mathrm{m}^{3} \mathrm{cell}^{-1}\right] \cdot\left[10^{-9} \mathrm{~mm}^{3} \mu \mathrm{m}^{-3}\right] \cdot\left[0.22 \mathrm{mg} \mathrm{C} \mathrm{mm}{ }^{-3}\right] \cdot\left[10^{-3}\right.$ $\left.\mathrm{g} \mathrm{mg}^{-1}\right]$.

c $\mathrm{mg} \mathrm{P} \mathrm{m}^{-2}=[\mathrm{POC}$ in $\mathrm{BM}] \cdot 50 \mathrm{mg} \mathrm{P} \mathrm{g}^{-1} \mathrm{C}$.

${ }^{d}$ Găchter et al. (1988).

e Jordan et al. (1985).

f Boström et al. (1985).

${ }^{g}$ Laczko (1988).

${ }^{\text {h }}$ Jones et al. (1979).

i $\mathrm{BM}=\left[\mathrm{BV} \mathrm{g}{ }^{-1} \mathrm{DW}\right] \cdot[0.1 \mathrm{~g} \mathrm{DW} \mathrm{cm}-1] \cdot\left[0.22 \mathrm{mg} \mathrm{C} \mathrm{mm}{ }^{-3} \mathrm{BV}\right] \cdot\left[10^{4} \mathrm{~cm}^{3} \mathrm{~m}^{-2}\right]$.

k Assumption: total areal $\mathrm{BM}=2 \cdot$ areal $\mathrm{BM}$ of top $\mathrm{cm}$.

${ }^{1} \mathrm{BM}=2 \cdot\left[\mathrm{CN} \mathrm{g}^{-1} \mathrm{DW}\right] \cdot\left[0.1 \mathrm{~g} \mathrm{DW} \mathrm{cm}{ }^{-3}\right] \cdot\left[0.5 \mu \mathrm{m}^{-3} \mathrm{cell}^{-1}\right] \cdot\left[0.22 \mathrm{mg} \mathrm{C} \mathrm{mm}{ }^{-3}\right] \cdot\left[10^{-9} \mathrm{~mm}^{3} \mu \mathrm{m}^{-3}\right] \cdot\left[10^{4} \mathrm{~cm}^{3} \mathrm{~m}^{-2}\right] \cdot\left[10^{-3}\right.$ $\left.\mathrm{g} \mathrm{mg}^{-1}\right]$.

ticulate organic carbon in bacterial biomass $\left(\mathrm{POC}_{\text {bact }}\right)$, substrate consumption (CS), specific growth rate $(\mu)$ and growth yield $(\mathrm{Y})$ are related as follows:

$$
\mathrm{BP}=\mu \cdot\left(\mathrm{POC}_{\mathrm{bact}}\right)=\mathrm{Y} \cdot(\mathrm{CS}) .
$$

Solving equation (2) for $\mathrm{POC}_{\text {bact }}$ allows one to estimate bacterial POC as a function of $\mu, \mathrm{Y}$ and 
CS. We estimated that yearly substrate consumption might equal $10 \%$ of primary production. According to Boström \& Törnblom (1990), growth yield of bacterial communities varied between 0.17 and 0.4 (average of about 0.3 ), and average growth rate of sediment bacteria at temperatures between $4{ }^{\circ} \mathrm{C}$ and $5{ }^{\circ} \mathrm{C}$ was about 0.0005 day $^{-1}$ or $18 \mathrm{yr}^{-1}$. From this it follows that bacterial biomass can be expressed in $\mathrm{g} \mathrm{C} \mathrm{m}^{-2}$ as

$$
\begin{aligned}
\text { POC }_{\text {bact }} & =\mathrm{Y} \cdot(\mathrm{CS}) / \mu \\
& =0.3 \cdot 0.1 \cdot \text { Prod. } / 0.18 \\
& =0.17 \mathrm{yr} \cdot \text { Prod. }
\end{aligned}
$$

Assuming again a $C: P$ ratio of 20 , the $P$ fixed in bacterial biomass $\left(\mathrm{P}_{\text {bact }}\right)$ can be estimated as

$$
\begin{aligned}
\mathrm{P}_{\text {bact }} & =\mathrm{POC}_{\mathrm{bact}} / 20 \\
& =0.0085 \mathrm{yr} \mathrm{gP} / \mathrm{gC} \cdot \text { Prod. }
\end{aligned}
$$

Taking into account all uncertainties related to the various assumptions, equation (3) agrees well with equation (1). Thus, the two independent approaches predict a similar relationship between $\mathbf{P}_{\text {bact }}$ and primary production.

$\mathbf{P}_{\text {bact }}$ an also be related to $\mathbf{P}$ that settled to the lake bottom with organic detritus $\left(\mathrm{P}_{\text {settled }}\right)$. If $20 \%$ of organic $\mathrm{C}$ assimilated settles to the lake bottom, then $\mathrm{P}_{\text {settled }}$ can be estimated as

$$
\mathbf{P}_{\text {settled }}=0.2 \cdot \operatorname{Prod} \cdot(1 / \mathrm{C}: \mathrm{P})
$$

where $\mathrm{C}: \mathrm{P}$ is the $\mathrm{C}$ to $\mathrm{P}$ weight ratio of the settled seston. Combining (1) and (3) with (4) yields

$$
\mathbf{P}_{\text {bact }} / \mathbf{P}_{\text {settled }}=(0.025 \text { to } 0.043) \cdot(\mathrm{C}: \mathrm{P})
$$

In oligotrophic lakes, the $\mathrm{C}: \mathrm{P}$ ratio of settling detritus can be as high as 200; whereas in eutrophic lakes, it is close to 40 (Gächter \& Bloesch, 1985). Thus, in oligotrophic lakes, the $P$ fixed in benthic bacteria might exceed the annual flux of $\mathbf{P}$ to the sediment 5- to 9-fold; whereas in eutrophic lakes, $\mathbf{P}_{\text {bact }}$ is expected to equal 1 to 2 times the annual flux of $\mathbf{P}$ to the sediment. Since bacteria are concentrated in the sediment close to the surface, these high values suggest that in this layer a substantial part of the $\mathbf{P}$ might be incorporated in bacterial biomass.

At spring overturn, the areal $P$ content of a lake can be obtained by multiplying its average concentration times its average depth. As shown in Fig. 2, in shallow lakes the estimated $\mathbf{P}$ incorporated in sediment bacteria might exceed the amount present in the water. Thus, a partial release of $\mathrm{P}$ incorporated in benthic bacteria could lead to a significant increase of the $\mathrm{PO}_{4}$ pool available for primary producers, if the released $\mathrm{P}$ does not become sorbed to abiotic surfaces or is precipitated in the sediment. On the other hand, it seems unlikely that seasonal changes in bacterial biomass or changes of its $\mathbf{P}$ content could significantly alter the $\mathbf{P}$ content of the water column in deep lakes.

\section{Evidence for bacterial $P$ from sequential $P$ extraction}

Boström et al. (1985) extracted various forms of sedimentary $\mathbf{P}$ from Lake Vallentunasjön. They distinguished between loosely bound $\mathrm{P}, \mathrm{Fe}$ and bound $\mathrm{P}, \mathrm{Ca}$ bound $\mathrm{P}$ and residual $\mathrm{P}$ consisting mainly of organic $\mathrm{P}$ but also including the inert fraction. They classified about $75 \%$ of total $\mathrm{P}$ in surface sediments $(0-2 \mathrm{~cm})$ of Lake Vallentunasjön as residual $\mathbf{P}$ (Fig. 3). About $50 \%$ of this fraction was suddenly released from the sediment when the $\mathrm{O}_{2}$ concentration in the hypolimnion

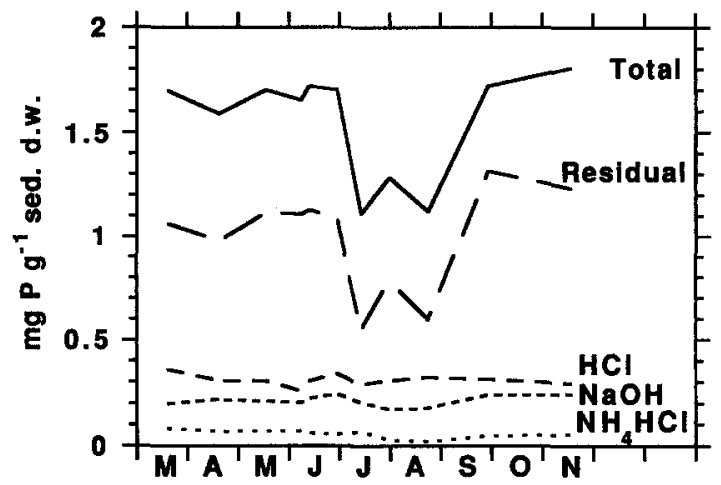

Fig. 3. Seasonal variation in concentration of total $P$ and different $\mathbf{P}$ fractions in surface sediments $(0-2 \mathrm{~cm})$ of Lake Vallentunasjön; redrawn from Boström et al. (1985). 
decreased from about $10 \mathrm{mg} \mathrm{liter}^{-1}$ to $2 \mathrm{mg} \mathrm{li-}$ $\operatorname{ter}^{-1}$ in July. It increased rapidly to its original concentration when the $\mathrm{O}_{2}$ concentration increased, indicating that release and uptake were reversible, redox-dependent processes. The redox-dependent dissolution and formation of solid $P$ could be explained by dissolution and formation of inorganic phosphate sorbed to iron oxyhydroxides. However, in the extraction scheme applied by these investigators, inorganic $P$ adsorbed to Fe would have been extracted as SRP in the $\mathrm{NaOH}-\mathrm{P}$ fraction, a fraction that was rather constant throughout the observed period. Boström et al. (1985) suggested that an increase in mineralization rate, lysis of bacteria and other organisms, or release of $\mathbf{P}$ from bacteria under anoxic conditions could have contributed to the observed loss of $\mathbf{P}$ from the sediment.

Recently, Uhlmann et al. (1990) extracted P from activated sludge according to the extraction scheme of Psenner et al. (1988) and in a separate extraction with hot water. They analyzed $\mathrm{NaOH}$ extracts and hot water extracts using NMR spectroscopy, a technique that allows poly-P to be identified. Using the method of Psenner et al. (1988), the major part of the total $P$ was recovered as non-reactive $\mathrm{P}$ (NRP) in the $\mathrm{NaOH}$ fraction ('residual $\mathrm{P}$ ' in the terminology of Boström et al., 1985). Most of this $P$ was identified as inorganic poly-P. These results suggest that the 'residual P' observed in the sediment of Lake Valentunasjön was not necessarily of organic nature. Changes in the residual $P$ could well be interpreted as hydrolysis of inorganic poly-P under anaerobic conditions and reformation of poly-P when $\mathrm{O}_{2}$ concentrations close to the lake bottom $(4 \mathrm{~m})$ again reached $10 \mathrm{mg} \mathrm{liter}^{-1}$.

Since production and dissolution of poly-P could be the major processes that contribute to transient storage of $\mathrm{P}$ in a nearly constant microbial benthic biomass, there is an obvious need to have a method available to quantify poly-P concentrations in sediments. As long as poly-P cannot be measured directly in sediments, the quantitative contribution of benthic bacteria to sudden redox-dependent release and fixation of $P$ remains speculative and obscure.
Uhlmann et al. (1990) suggested that the nonreactive $\mathrm{P}$ in the $\mathrm{NaOH}$ fraction was a good measure of poly-P. This conclusion needs to be further tested. It might be valid for 'young' activated sludge with a $\mathrm{P}$ content as high as $10 \%$ of dry weight. In sediments with a higher content of organic compounds and a lower $\mathrm{P}$ content, a substantial part of the NRP in the $\mathrm{NaOH}$ fraction might, however, be incorporated in the refractory organic fraction.

\section{Contribution of bacteria to production of refractory organic $P$ compounds}

\section{Theoretical considerations}

Although bacteria require a minimum amount of $P$ and can store it excessively if supply exceeds their demand and redox conditions are favourable, they are only a transient sink for P. When they die, decay and become decomposed by those which survive, part of the previously fixed $\mathbf{P}$ might be assimilated by their decomposers, part may be released as inorganic $P$, and part might eventually become dissolved or particulate refractory organic $\mathbf{P}$ compounds.

Generally, in deep lakes about $80 \%$ of $\mathrm{C}$ assimilated by primary producers is recycled in the epilimnion. About $20 \%$ settles across the thermocline and reaches the sediment. There, about half of it becomes mineralized within a few years. The remaining $10 \%$ is buried in the sediment as refractory organic carbon compounds. Table 3 exemplifies mineralization of settled organic material and production of refractory organic material in lake sediments. As it illustrates, decomposition of bacterial biomass is always coupled with production of new biomass and, hence, with the production of additional refractory organic carbon. Thus, after complete mineralization of the bacterial biomass about $16 \%$ of the initial bacterial $\mathrm{C}$ remains as refractory $\mathrm{C}$.

Of course, a $50 \%$ mineralization could also be explained if we had chosen other assumptions regarding the content of refractory organic POC in settled seston and benthic bacteria. Possible 
Table 3. Scheme exemplifying production of refractory organic material in lake sediments. Assumptions: $20 \%$ of $\mathrm{C}$ assimilated by primary producers settles to the sediment. $9 \%$ of $\mathrm{C}$ assimilated by primary producers and by bacteria are refractory. Bacteria mineralize organic $\mathrm{C}$ with an efficiency of $50 \%$.

\begin{tabular}{lllll}
\hline $\begin{array}{l}\text { POC to be } \\
\text { mineralized }\end{array}$ & $\begin{array}{l}\text { Refractory } \\
\text { POC }\end{array}$ & $\begin{array}{l}\text { POC in } \\
\text { bacteria }\end{array}$ & $\mathrm{CO}_{2}$ \\
\hline 20 & 9 & 5.5 & 5.5 \\
5.5 & 0.495 & 2.5025 & 2.5025 \\
2.5025 & 0.22523 & 1.1386 & 1.1386 \\
1.1386 & 0.10248 & 0.51806 & 0.51806 \\
0.51806 & 0.04663 & 0.23572 & 0.23572 \\
0.23572 & 0.021215 & 0.10725 & 0.10725 \\
0.10725 & 0.009653 & 0.048799 & 0.048799 \\
0.048799 & 0.004392 & 0.022204 & 0.022204 \\
0.022204 & 0.001998 & 0.010103 & 0.010103 \\
& & & & \\
Sum & & 9.90659 & & 10.08324 \\
\hline
\end{tabular}

extreme, but unrealistic assumptions would be:

- $50 \%$ of the settled POC is refractory, and bacteria produce no refractory $\mathrm{POC}$; or

- all sestonic POC is decomposable, but bacterial POC is completely refractory.
As more precise information is lacking, however, it seems reasonable to assume equal percentages of refractory organic material in the biomass of all trophic levels.

As long as we are not able to measure production of refractory organic material by bacteria, this discussion is mainly of didactical value. However, it shows that bacteria contribute to the production of refractory organic material. Even if we know that bacterial biomass and activity might change seasonally, it has to be in cyclic steady state in a lake of constant trophic state. Accordingly, regardless of the bacterial pool size, on a yearly basis, uptake rates of all nutrients need to be compensated by loss rates. Thus, contrary to mineral sites, bacteria can never act as a terminal sink for P. However, because they produce some refractory organic $\mathbf{P}$ compounds they contribute not only to the recycling, but also to the removal of bioavailable $\mathbf{P}$ from aquatic systems. Let us assume (as sketches in Fig. 4) that at steady state, bacteria consume per year an amount $\mathrm{l}_{\mathrm{C}}$ of organic $C$ and an amount of $I_{P}$ of $P$ (i.e., the $C: P$ ratio of its substrate equals $l_{C} / I_{P}=a$ ). Because at

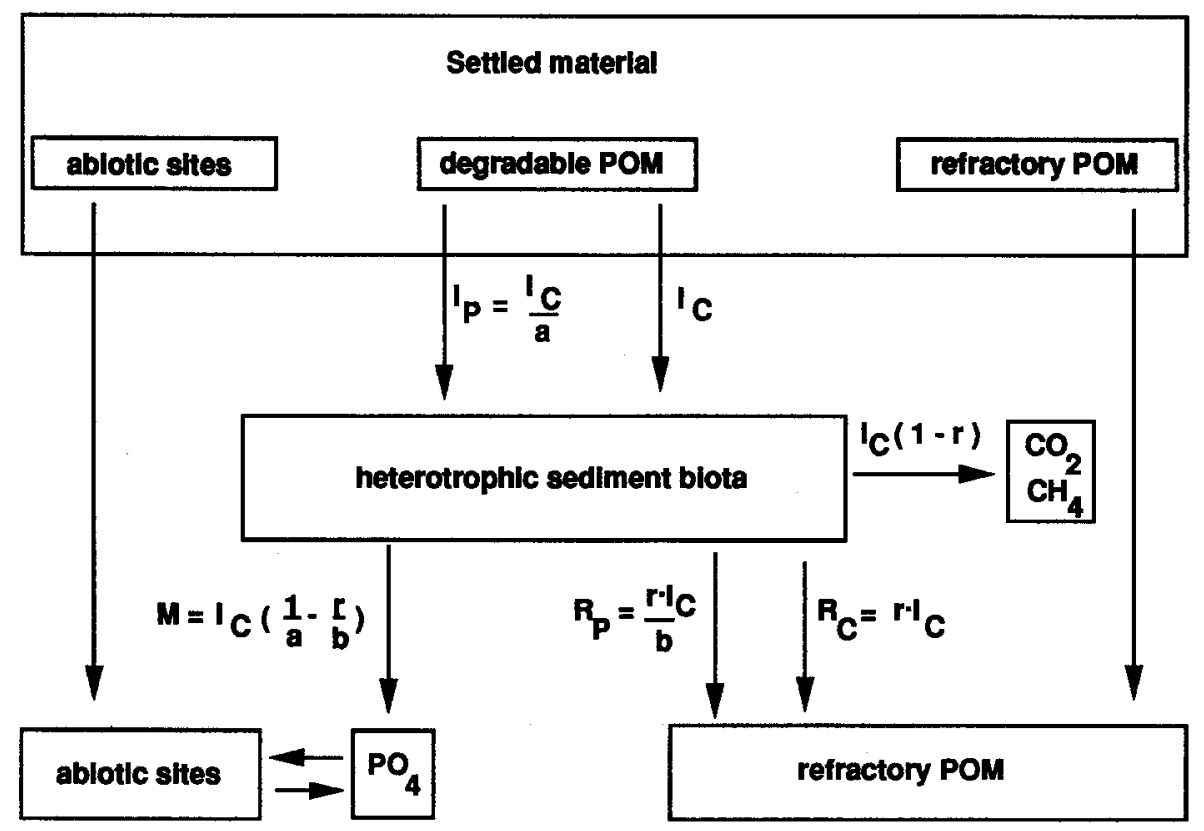

Fig. 4. Release of $\mathrm{PO}_{4}$ and production of refractory organic $\mathbf{P}$ compounds by sediment bacteria (see text for explanation of symbols). 
steady state the pool size of bacteria does not change, net production of the bacterial community equals zero. It transforms bioavailable organic material into $\mathrm{CO}_{2}\left(\mathrm{CH}_{4}\right), \mathrm{PO}_{4}$ and refractory organic material. Hence, production of refractory organic carbon $\left(\mathrm{C}_{r}\right)$ can be formally expressed as $r \cdot I_{C}$ where $r$ defines the fraction of the total bioavailable organic $\mathrm{C}$ that is transformed by bacteria to refractory organic carbon. Production of refractory organic $\mathrm{P}$ equals $r \cdot \mathrm{I}_{\mathrm{C}} / b$, where $b$ is the $\mathrm{C}: \mathrm{P}$ ratio in the refractory organic material produced by the bacteria.

At steady state the amount $P$ 'mineralized' and released as inorganic $\mathrm{PO}_{4}$ (M) must equal $\mathrm{I}_{\mathrm{P}}-r \cdot \mathrm{I}_{\mathrm{C}} / b$. Relating mineralization to input yields

$$
\mathrm{M} / \mathrm{IP}=1-r \cdot a / b
$$

indicating that bacteria mineralize $\mathbf{P}$ more efficiently at lower values of $r$, lower C:P ratios of the substrate, and higher $\mathrm{C}: \mathrm{P}$ ratios of the produced refractory material. The absolute values of $r, a$ and $b$ are currently unknown.

For the following reasons, the values of $a$ and $b$ cannot be determined simply by measuring the $\mathrm{C}: \mathrm{P}$ ratio of the settling material and of refractory organic material in deep sediments, respectively:

(1) settled organic material is an unknown composition of degradable and refractory organic material with unknown C:P ratios, and

(2) refractory organic C pool in deep sediments is likely dominated by refractory organic C originating from settled organic material.

Even if the absolute values of $a, b$ and $r$ are not known, relative release rates can be predicted from equation (6). In oligotrophic lakes, sediment bacteria mineralize organic $P$ compounds less efficiently than in eutrophic lakes, because in oligotrophic lakes a larger fraction of the settled organic material is decomposed aerobically (causing a higher growth yield and, hence, larger values of $r$ and because the settling material has a higher $\mathrm{C}: \mathrm{P}$ ratio suggesting a higher value of $a$ than in eutrophic lakes.

Sediments will release no $P$ when the integrated rate of bacterial refractory $P$ production plus abiotic and biotic immobilization equal the supply rate of labile $\mathrm{P}$ to the sediment surface. Thus, very likely, release rates of $\mathrm{PO}_{4}$ from sediments in oligotrophic lakes are small not only because little organic material is decomposed and the $\mathrm{PO}_{4}$ sorbed to inorganic sites is small in comparison to their sorption capacity, but also because bacteria mineralize organic $\mathbf{P}$ compounds less efficiently than in eutrophic lakes.

\section{Refractory organic $P$ compounds in lake sediments}

Refractory organic material includes refractory $\mathbf{P}$ compounds, partly as cell remains but also as
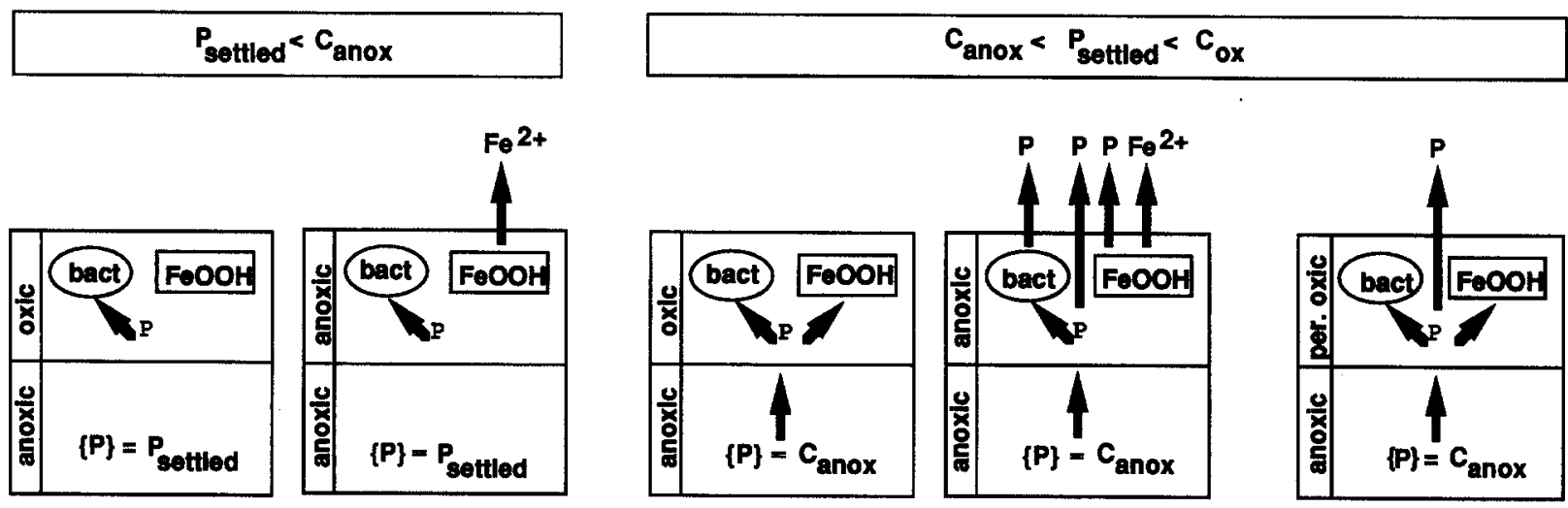

Fig. 5. Schematic presentation of $\mathbf{P}$ sinks and sources in the sediments of oligotrophic and eutrophic lakes under oxic and anoxic conditions. $\{\mathbf{P}\}$ is total $\mathbf{P}$ concentration (particulate + dissolved). 
high molecular weight organic compounds either dissolved in interstitial water or adsorbed to solid surfaces. Lean (1973a, b), Lean \& Rigler (1974) and Rigler (1973) identified in epilimnetic waters four $\mathrm{P}$ compartments: $\mathrm{PO}_{4}$, low molecular weight organic $\mathrm{P}$ (XP), a colloidal high molecular weight $P$ fraction (HMP) and particulate $P$ incorporated in seston (PP). XP was excreted by planktonic microorganisms and, after polycondensation formed HMP, which was no longer bioavailable to phytoplankton. Hence, HMP might be called refractory. Filtration as well as poisoning of the water with formaldehyde (Jackson \& Schindler, 1975; Brassard \& Auclair, 1984) prevented labelling of XP and HMP when ${ }^{32} \mathbf{P}$ was added as $\mathrm{PO}_{4}$, indicating that the formation of $\mathrm{XP}$ and HMP was mediated by microorganisms. There is no reason why sediment bacteria should behave differently. Thus, they as well probably produce not only solid refractory $P$ compounds as cell remains but also HMP compounds, which may either be dissolved in the interstitial water or adsorbed to organic and inorganic surfaces. However, it needs to be demonstrated that these compounds are 'refractory' on the time scale of years.

In Psenner's extraction scheme (Psenner et al., 1984; Psenner \& Pucsko, 1988; Psenner et al., 1988), most organic $P$ compounds are recovered as NRP in the $\mathrm{NaOH}$ fraction. Of course, this fractionation does not discriminate between degradable and refractory compounds and, as demonstrated by Uhlmann et al (1990), it may include inorganic poly-P as well. However, if we assume that the quality of settling material did not change during past years, then, with increasing age of the sediment and, hence, with increasing sediment depth, the ratio between degradable and refractory organic compounds probably decreases. In addition, volutin granules (rich in poly-P) disappear with increasing sediment depth (Hupfer \& Uhlmann, 1990). Thus, the NRP fraction extracted with $\mathrm{NaOH}$ from sediments sampled a few centimetres below the sediment surface might provide a valid estimate of refractory $\mathbf{P}$ compounds buried in sediments.

From results obtained by Williams et al. (1976) in Lake Erie, it can be deduced that in sediment layers that were deposited 23 to 36 years before sampling, $30 \%$ to $>50 \%$ of the buried $\mathrm{P}$ was organic refractory $\mathbf{P}$, if the allochthonous apatite-P was disregarded. In Lakes Skaha and Wood, 15 to $32 \%$ and 25 to $70 \%$ of the nonapatite $P$ sampled deeper than $10 \mathrm{~cm}$ below the sediment surface was organic $P$ (Williams, 1973). In Kleiner Montigglersee, 40 to $60 \%$ of the $P$ was of organic nature in the top $10 \mathrm{~cm}$ of the sediment (Psenner et al., 1984); and in the oligotrophic but meromictic Piburger See, 75 to $>90 \%$ of the total $P$ was organic in the top $8 \mathrm{~cm}$ of the sediment.

Obviously, in many cases, after initial mineralization of the autochthonously formed particulate $\mathbf{P}$, a large fraction is buried as organic $\mathbf{P}$ in sediment. Thus, bacterial mineralization of organic $P$ is not very efficient, or, as discussed above, bacteria may even contribute to the formation of such compounds.

\section{Experimental evidence of biological control of phosphorus fluxes across the sediment/water interface}

In order to test whether the transfer of $\mathbf{P}$ across the sediment/water interface is controlled not only by inorganic chemical equilibria but also by bacteria, bacterial activity could be suppressed by heat, by gamma irradiation or by addition of antibiotics or poisons. If bacteria play an important role, then inactivation of bacteria will markedly alter $\mathbf{P}$ fluxes. However, it must be kept in mind that such experiments can at best give qualitative results, because they compare a living sediment with one that has been poisoned just recently. A true comparison would require a control with sterile deposition of settling seston during at least several years.

Figure 6 shows 10 interacting $P$ compartments that need to be considered when transfer of $P$ across the sediment/water interface is discussed. If ${ }^{32} \mathrm{PO}_{4}$ is added to the sediment-overlying water, it eventually will uniformly label all of the mobile $P$ compartments (i.e., those directly or indirectly in exchange with the $\mathrm{PO}_{4}$ pool). Bacterial activity controls the labelling of particulate $\mathrm{P}$ incorpo- 


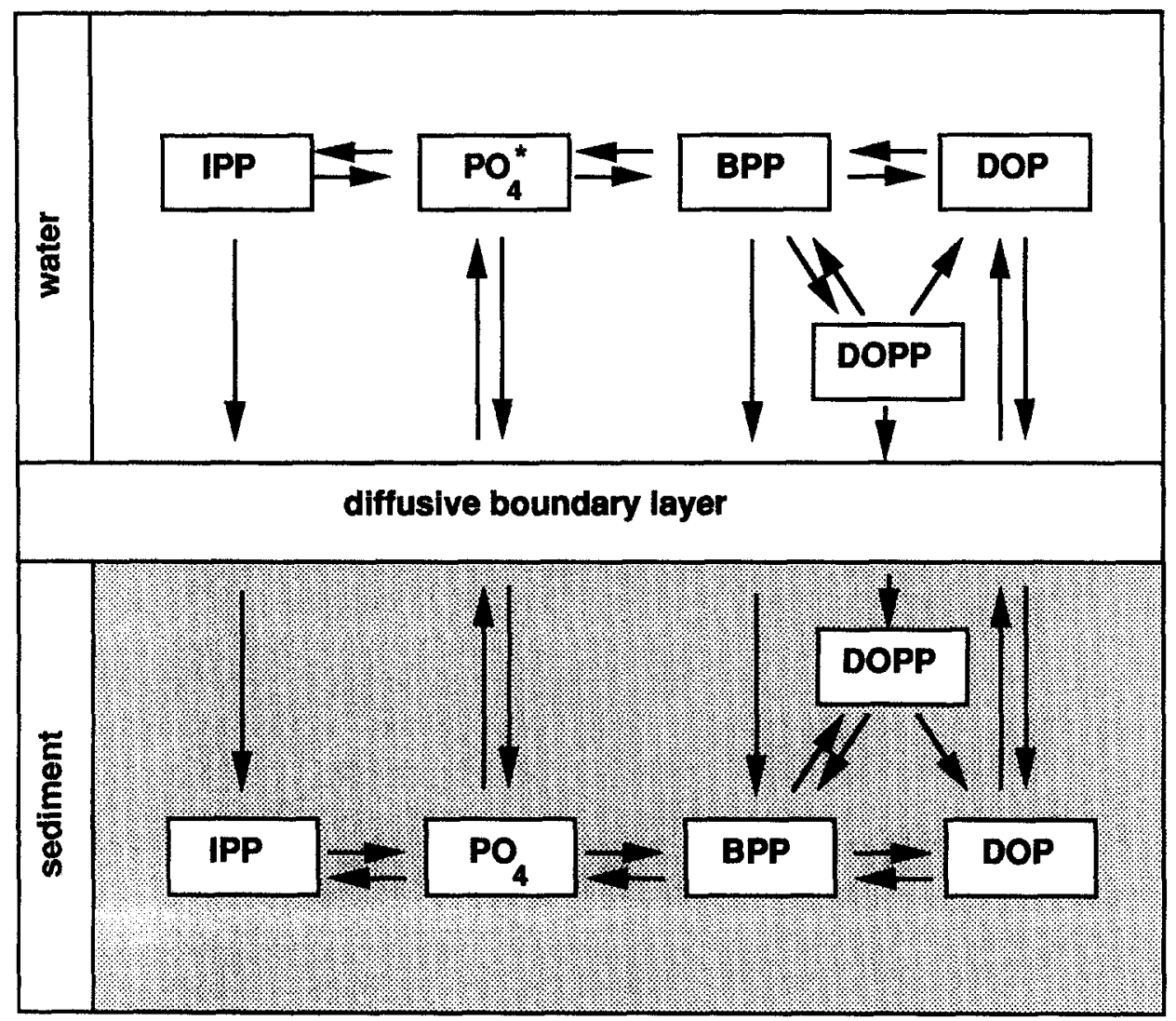

Fig. 6. $\mathrm{P}$ compartments involved in the exchange of ${ }^{32} \mathrm{PO}_{4}\left(\mathrm{PO}_{4}^{*}\right)$ across the sediment/water interface: IPP $=$ inorganic particulate $\mathrm{P}, \mathrm{PO}_{4}=$ ortho-P, $\mathrm{BPP}=$ particulate $\mathrm{P}$ in biomass, $\mathrm{DOP}=$ dissolved organic $\mathrm{P}, \mathrm{DOPP}=$ detrital organic particulate $\mathrm{P}$.

rated in bacteria (BPP), dissolved organic $\mathbf{P}$ (DOP) and detrital bacterial $\mathrm{P}$ (DPP). ${ }^{32} \mathrm{P}$ is transferred to the sediment as $\mathrm{PO}_{4}$, as dissolved organic $\mathbf{P}$ (DOP), as inorganic particulate or colloidal $\mathbf{P}$ (IPP), as particulate $\mathrm{P}$ incorporated in bacteria (BPP) or in organic detritus (DPP). Transport of dissolved species $\left(\mathrm{PO}_{4}, \mathrm{DOP}\right)$ is controlled by molecular diffusion through the diffusive boundary layer, separating the well mixed water from the sediment. Transport of particulate species (IPP, BPP and DPP) is controlled by their settling velocities.

In the sediment, inactivation of bacteria retards or even prevents the labelling of BPP, DOP and DPP. As a consequence, the specific activity of the $\mathrm{PO}_{4}$ pool of the pore water increases faster if sediment bacteria are inactive. Since diffusion of ${ }^{32} \mathrm{PO}_{4}$ from the water to the sediment depends on its concentration gradient across the interface, inactivation of sediment bacteria likely results in a lower uptake rate of ${ }^{32} \mathrm{P}$ in a later phase of an experiment and in a higher steady-state ${ }^{32} \mathrm{PO}_{4}$ activity in the sediment-overlying water.

Hayes \& Phillips (1958) described results from various experiments in which they labelled sediment-overlying water with ${ }^{32} \mathrm{PO}_{4}$ and compared the transfer of ${ }^{32} \mathrm{P}$ to the sediment in presence and in absence of bacterial activity (bacterial activity in the overlying water was suppressed with the antibiotics terramycin or tetracycline). They found that inactivation of suspended bacteria increased the initial flux of ${ }^{32} \mathbf{P}$ from the water to the sediment drastically.

Jackson \& Schindler (1975) conducted a similar experiment with water from lake 239 and sediment from Lake 227 . They inactivated bacteria by addition of $0.48 \%$ formalin at the outset of the experiment and monitored the loss of ra- 
dioactivity in the filtrate of the sediment-overlying water. In the system containing only lake water but no mud, losses of ${ }^{32} \mathrm{PO}_{4}$ were due to uptake by suspended matter (bacteria, planktonic organisms, organic and inorganic detritus) and to possible adsorption of ${ }^{32} \mathrm{P}$ to the walls of the container. In addition to the components mentioned above, two other systems contained sediment as an additional solid phase; one was poisoned with formaldehyde, the other was not. The three treatments can be ranked according to decreasing rates of radioactivity from solution, as follows: plankton with sediment $>$ formalin-treated plankton with sediment $=$ plankton with no sediment. At first, these results might seem to contradict those reported by Hayes \& Phillips (1958). Whereas Hayes \& Phillips (1958) concluded that suspended microorganisms retarded the transfer of ${ }^{32} \mathrm{P}$ to the sediment surface, Jackson \& Schindler (1975) concluded that 'microorganisms accelerated the transfer of dissolved ${ }^{32} \mathbf{P}$ to the mud'. However, this conclusion is misleading, because Jackson \& Schindler (1975) showed only the removal of dissolved ${ }^{32} \mathrm{P}$ and not of total ${ }^{32} \mathrm{P}$ from the water.

In summary, it can be concluded from the results presented by Hayes \& Phillips (1958) and Jackson \& Schindler (1975) that 'suspended bacteria' retard the transfer of ${ }^{32} \mathrm{PO}_{4}$ from the water to the sediment. This effect is due to scavenging of ${ }^{32} \mathrm{PO}_{4}$ in dissolved and particulate compounds, which move more slowly from the water to the sediment than does the ${ }^{32} \mathrm{PO}_{4}$. Bacteria were able to do so because of $P$ content of the compartments BPP and DOP were large compared to the $\mathrm{PO}_{4}$ concentration of the sediment-overlying water. However, it cannot be decided from such experiments if 'sediment bacteria' contain a significant amount of the total $P$ content and if they significantly and directly control the flux of $\mathrm{P}$ across the sediment/water interface.

Hupfer \& Uhlmann (1991) partly inactivated bacteria in sediment cores by the addition of antibiotics to the sediment-overlying water after it became anoxic. In the presence of active bacteria (no antibiotics added), the sediment took up $5.1 \mathrm{mg} \mathrm{P} \mathrm{m}^{-2}$ day $^{-1}$ and $9.5 \mathrm{mg} \mathrm{P} \mathrm{m}^{-2}$ day $^{-1}$ when $\mathrm{NO}_{3}$ - or $\mathrm{O}_{2}$ were available as the oxidant. When bacteria were inactivated, $\mathrm{P}$ uptake switched to net release of $\mathrm{P}\left(12.7 \mathrm{mg} \mathrm{P} \mathrm{m}^{-2} \mathrm{day}^{-1}\right.$ and $9.8 \mathrm{mg} \mathrm{P} \mathrm{m}^{-2} \mathrm{day}^{-1}$ in the presence of $\mathrm{NO}_{3}^{-}$or $\mathrm{O}_{2}$ respectively). This observation suggests that antibiotics

(1) induced release of $P$ from bacteria, or

(2) decreased the ability of the sediment to immobilize $\mathrm{P}$ either by chemical/physical adsorption or by biological uptake.

Even if these results do not allow discrimination between the two potential mechanisms, it seems unlikely that antibiotics decreased the abiotic sorption capacity of the sediment; $\mathrm{O}_{2}$ is known to oxidize $\mathrm{Fe}^{2+}$ quickly at neutral $\mathrm{pH}$, even in the absence of bacterial activity. Bacteria compete with $\mathrm{Fe}^{2+}$ for $\mathrm{O}_{2}$ and, in addition, produce protons while decomposing organic material; hence, they lower the abiotic oxidation rate of $\mathrm{Fe}^{2+}$ in the sediment. Therefore, inactivation of bacteria is expected to increase, rather than decrease absorption of $\mathrm{PO}_{4}$ by iron oxyhydroxides. Yet, the contrary was observed: In the presence of $\mathrm{O}_{2}$ or $\mathrm{NO}_{3}^{-}$, the control sediments took up $\mathrm{P}$ from the overlying water but the sediments released $P$ when the bacterial activity was suppressed. This indicates that antibiotics either lowered the $\mathbf{P}$ uptake of bacteria or even induced $\mathbf{P}$ lysis from biota.

Sinke \& Cappenberg (1988) gamma-irradiated sediment cores and compared initial short-term $\mathbf{P}$ release rates of irradiated (sterilized) and nonirradiated cores at temperatures ranging from 10 to $80^{\circ} \mathrm{C}$. Gamma irradiation killed sediment biota and likely induced cell lysis and release of P. $\mathbf{P}$ released from organisms equilibrates with abiotic surfaces in the sediment and diffuses to the overlying water. Increasing temperature enhances mineralization, favour desorption and increases diffusion.

As shown in Fig. 7, release rates of irradiated cores increased linearly with temperature and clearly exceeded those of the non-sterilized sediments, except for the highest temperatures (60 to $80^{\circ} \mathrm{C}$ ). In the lower temperature range, the differences in release rates between sterilized and non-sterilized sediment increased with increasing 


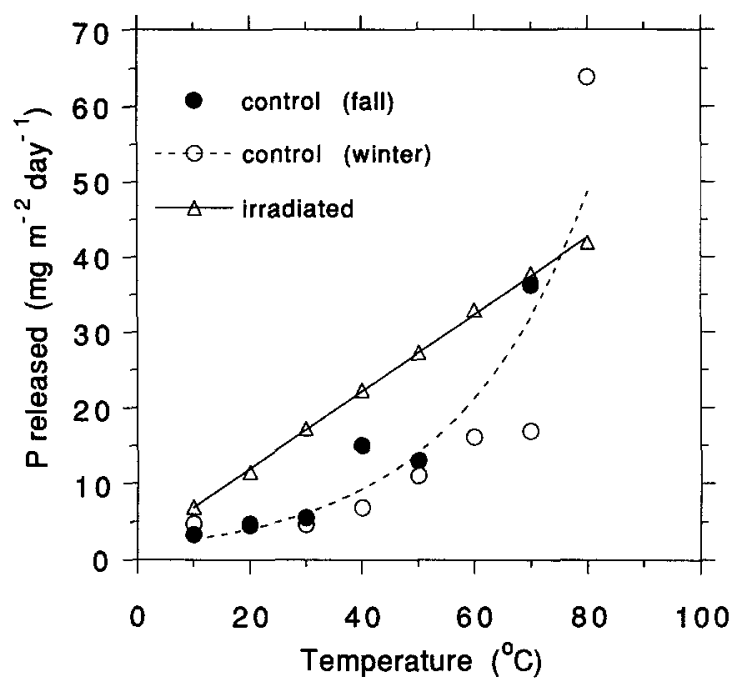

Fig. 7. Release of total dissolved $\mathbf{P}$ from gamma-irradiated and non-sterilized sediment cores; redrawn from Sinke \& Cappenberg (1988).

temperature, in agreement with the expected increase of equilibrium concentration in the interstitial water and the increased molecular diffusion. If temperature exceeds a critical value, it gradually causes death of the most sensitive organisms and, hence, also induces lysis. Thus, release rates did not differ between irradiated and non-irradiated samples at 70 to $80^{\circ} \mathrm{C}$, probably it did not matter whether biota were killed by irradiation or by the high temperature.

Experiments conducted with sediments of Lac Tantaré, Quebec (Gächter et al., 1991), support the findings of Sinke \& Cappenberg (1988). Anoxic sediment sampled in the deepest part of the lake in October 1990 was sterilized with formaldehyde $(0.16 \%)$, heat $\left(20\right.$ minutes at $\left.121{ }^{\circ} \mathrm{C}\right)$ or gamma irradiation ( 3 million Rads). Seventeen days after sterilization, total dissolved $P$ concentration ([TDP]) was measured in the filtered $(0.45 \mu \mathrm{m})$ interstitial water that was isolated by centrifugation. [TDP] in the unsterilized control $\left(17.5 \pm 7.5 \mu \mathrm{g} \mathrm{liter}^{-1}\right)$ was significantly lower than in the sterilized samples (heat: $388 \pm 71 \mu \mathrm{g} \mathrm{liter}^{-1}$; formaldehyde: $118 \pm 42 \mu$ liter $^{-1}$; radiation: $102 \pm 7 \mu \mathrm{g} \mathrm{liter}^{-1}$ ). This significant increase of $\mathbf{P}$ concentration of the interstitial water underestimates the amount of $\mathbf{P}$ incorporated in microor- ganisms, probably because not all $\mathbf{P}$ was released and part of it was readsorbed to abiotic surfaces.

Such experimental results strongly support the hypothesis that bacteria incorporate $\mathbf{P}$ in their biomass that otherwise would contribute to increased interstitial water concentrations and, hence, to increased fluxes of $P$ from the sediment to the overlying water. However, they do not allow us to quantify the bacterial contribution. In nature, sediments never become sterile. When bacteria die, e.g. due to changing redox conditions, they will be replaced by other species, better adapted to the new environment. As a consequence, part of the $\mathbf{P}$ released from dead bacteria will be taken up by their successors. Thus, under natural conditions, $P$ released from biota always is partly masked by succession.

\section{Interference of bacteria with the coupling of iron and phosphorus cycling in an aerobic sediment surface}

It is well documented and widely accepted that aerobic sediment surfaces act as a $P$ trap, which under reducing conditions release part or all of the previously trapped P. Since every sediment surface is eventually buried and becomes anoxic, it will lose the amount of $\mathbf{P}$ that exceeds its anoxic retention capacity. Thus, as illustrated in Fig. 5 , the $P$ retention by lake sediments depends on the settling flux of particulate $P$ to the sediment $\left(P_{\text {settled, }}\right.$ expressed as $\mathrm{g} \mathrm{P} \mathrm{m}^{-2} \mathrm{yr}^{-1}$ ) and the $\mathrm{P}$ retention capacity of anoxic sediments $\left(C_{a n o x}\right.$, expressed as $\left.\mathrm{g} \mathrm{P} \mathrm{m}^{-2} \mathrm{yr}^{-1}\right)$. As long as $\mathbf{P}_{\text {settled }}$ does not exceed $C_{\text {anox }}$, the sediment will not release $P$ under either oxic or anoxic conditions, and diagenesis of the sediment will not result in an accumulation of $P$ at the sediment surface. If $P_{\text {settled }}$ exceeds $C_{\text {anox }}$, then the sediment surface is supplied with $\mathrm{P}$ from two sides: from above by settling particles, and from below by diffusion of dissolved $\mathbf{P}$ species originating from reductive dissolution of redox-dependent solid species. If the sediment surface is permanently oxic, it will accumulate $P$ until its $P$ content reaches its $P$ binding capacity $\left(C_{o x}\right)$ (Gächter, 1987). Then, the 
sediment starts to release $\mathbf{P}$ even under oxic conditions. If the sediment surface becomes periodically anoxic, it loses part of the $\mathrm{P}$ accumulated under previously oxic conditions. As a consequence of this 'anoxic regeneration', its $\mathrm{P}$ content may never reach $\mathrm{C}_{\text {ox }}$ and no $\mathrm{P}$ would be released under subsequent transient oxic conditions.

Thus, on a short-term basis, $P$ fluxes across the sediment/water interface may be controlled by redox-dependent chemical or biological mechanisms, such as precipitation and dissolution of iron oxyhydroxides which adsorb $\mathrm{PO}_{4}$, or redoxdependent uptake and release of $\mathbf{P}$ by microorganisms. Bacteria are known to be able to efficiently take up $\mathrm{PO}_{4}$ from solution, if the substrate that they decompose does not fulfil their requirements (e.g., Barsdate et al., 1974; Planas, 1978; Fenchel \& Blackburn, 1979; Fleischer, 1983; Lean \& White, 1983; Lean, 1984; Currie \& Kalff, 1984; Gächter et al., 1988; Stőckli, 1985). As a consequence, bacteria may have to complete with iron oxyhydroxides for $\mathrm{PO}_{4}$. It was experimentally demonstrated by Fleischer (1986) that they are able to compete successfully. Their demand for $\mathbf{P}$ increases as the $\mathrm{C}: \mathrm{P}$ ratio of the settled organic material increases. As discussed above, the C:P ratio of bacteria is approximately 20 . Assuming a yield of $50 \%$ for aerobic bacteria, bacteria are only expected to release $P$ if the $C: P$ ratio of their substrate is smaller than 40 . According to Gächter \& Bloesch (1985), the C:P ratio of settling seston exceeds this value largely in oligotrophic and mesotrophic lakes. Thus, especially at the sediment surface of oligotrophic lakes, aerobic bacteria may have to complete with abiotic sorption sites for $\mathrm{PO}_{4}$. In eutrophic aerobic lakes, the $\mathrm{C}: \mathrm{P}$ ratio of the settled organic matter is closer to 40 and, hence, might satisfy the needs of bacteria for $\mathbf{P}$. As a consequence, in eutrophic aerobic lakes, $P$ diffusing to the sediment surface might to a lager extent be trapped by iron oxyhydroxides.

In most cases, retention of $\mathrm{P}$ in an oxic sediment layer is very likely due to adsorption to abiotic surfaces as well as to fixation by microorganisms. In eutrophic lakes, aerobic bacteria might store excess $\mathrm{PO}_{4}$ as poly-P. If the sediment sur- face becomes anoxic, $P$ is released due to reductive dissolution of iron oxyhydroxides as well as due to the hydrolysis of poly-P in bacteria.

In oligotrophic lakes, where $\mathrm{P}_{\text {settled }}$ does not exceed $C_{\text {anox }}$, $P$ does not accumulate in the oxic sediment surface. A large fraction of the $P$ present is probably incorporated into not yet degraded organic material, into refractory compounds and into bacterial biomass. Since $P$ supply of the bacteria is limited, they probably store little or no poly-P, and if they successfully complete with abiotic surface complexation, little $\mathrm{PO}_{4}$ is adsorbed to iron oxyhydroxides. Hence, redox-dependent solid $\mathrm{PO}_{4}$ is probably not an important fraction of the total $P$, and reduction of the sediment surface does not result in a sudden release of $P$. This could explain why the classical model of the coupled $\mathrm{Fe}$ and $\mathrm{P}$ cycling was derived in highly eutrophic lakes, whereas the view that bacteria might be important in controlling $\mathbf{P}$ flux across the sediment/water interface was first suggested from investigations of oligotrophic lakes. For examples, Levine (1975) and Levine \& Schindler (1980) showed that hypolimnetic concentrations of $\mathrm{PO}_{4}$ rarely exceeded $1 \mu \mathrm{g} \mathrm{liter}^{-1}$ in Lakes 227 and $302 \mathrm{~S}$, even under anoxic conditions. Sorption of $\mathrm{PO}_{4}$ to redox-independent surfaces such as hydrated aluminium oxides or humic complexes could, however, also explain why anoxic conditions did not result in a sudden release of $\mathrm{PO}_{4}$ in these oligotrophic lakes.

\section{Summary and conclusions}

We have demonstrated that

(1) biomass of sediment bacteria is positively related to primary production or to the flux or organic matter to the sediment.

(2) most benthic bacteria are accumulated in a layer close to the sediment surface.

(3) the C:P ratio of bacteria is approximately 20 ; hence, it is significantly lower than that of phytoplankton, whose C:P ratio seems to vary between 200 and 40, depending on trophic state. Provided the $P$ supply is sufficient and redox conditions are appropriate, the $C: P$ 
ratio in bacteria can decrease to values as low as 5 , corresponding to a $\mathrm{P}$ content that is $10 \%$ of dry weight.

(4) in many lakes, a significant proportion of the permanently buried $\mathbf{P}$ is refractory organic $P$.

(5) comparing results obtained from experiments with sterilized and unsterilized sediments does not allow one to quantify directly the contribution of bacteria to $\mathrm{P}$ cycling across the sediment/water interface.

From this we conclude that

(1) sediment bacteria do not necessarily release $P$ when they mineralize settled organic detritus. Depending on the C:P ratio of their organic substrate and their growth yield, they might transiently even take up dissolved $\mathbf{P}$ from their environment in order to fulfil their nutritional requirement.

(2) the ratio between the amount of $\mathbf{P}$ fixed in sediment bacteria and the amount of $P$ being deposited per year as part of the organic material at the sediment surface increases with decreasing trophic state of a lake. In eutrophic lakes bacterial $\mathbf{P}$ in the sediment equals approximately 1 to 2 yrs worth of $\mathbf{P}$ deposition; whereas in oligotrophic lakes, it equals 5 to $9 \mathrm{yrs}$ worth of deposition.

(3) seasonal changes of the bacterial P pool size (changing biomass and/or changing $\mathrm{P}$ content) may affect transport of $\mathrm{P}$ across the sediment/water interface.

(4) sediment bacteria may contribute to the production of organic $\mathbf{P}$ compounds; in oligotrophic lakes, they probably convert a larger fraction of the assimilated $P$ into refractory organic $\mathbf{P}$ compounds than they do in eutrophic lakes. This mechanism stabilizes oligotrophic conditions.

In summary, we believe that, especially in shallow, oligotrophic lakes, bacteria may play a much more important role in $\mathbf{P}$ cycling across the sediment/water interface than has been generally assumed up to now. However, in order to test these conclusions unequivocally, techniques need to be developed to
(1) determine the $P$ content of sediment bacteria as a function of varying environmental conditions,

(2) measure poly-P in sediments,

(3) differentiate between refractory and bioavailable $P$, and

(4) study production and chemical nature of refractory $\mathbf{P}$ generated by sediment bacteria.

\section{Acknowledgements}

We thank Th. Cappenberg, R. Carignan, $M$. Hupfer, D. Uhlmann and two anonymous referees for their valuable suggestions on the manuscript.

\section{References}

Barsdate, R. J., T. Fenchel \& R. T. Prentki, 1974. Phosphorus cycle of model ecosystems: Significance for decomposer food chains and effect of bacterial grazers. Oikos 25: 239251 .

Borsheim, K. Y., G. Bratbak \& M. Heldal, 1990. Enumeration and biomass estimation of planktonic bacteria and viruses by transmission electron microscopy. Appl. envir. Microbiol. 56: 352-356.

Boström, B., M. Jannson \& C. Forsberg, 1982. Phosphorus release from lake sediments. Arch. Hydrobiol. Beih. Ergebn. Limnol. 18: 5-59.

Boström, B., I. Ahlgen \& R. Bell, 1985. Internal nutrient loading in a eutrophic lake reflected in seasonal variations of some sediment parameters. Verh. int. Ver. Limnol. 22: 3335-3339.

Boström, B., 1985. The role of Microcystis colonies, its mucilage and associated bacteria, for nutrient fluxes from sediments to lake water. - A working hypothesis. In: M. Enell, W. Graneli \& L.-A. Hansson (eds), Proc. 13th. Nordic Sump. on Sediments, Anneboda, Sweden: 6-8.

Boström, B., A.-K. Pettersson \& I. Ahlgren, 1989. Seasonal dynamics of a cyanobacteria-dominated microbial community in surface sediments of a shallow, eutrophic lake. Aquat. Sci. 51: 153-178.

Boström, B. \& E. Törnblom, 1990. Bacterial production, heat production and ATP-turnover in shallow marine sediments. Termochim. Acta 172: 147-156.

Brassard, P. \& J. C. Auclair, 1984. Orthophosphate uptake rate constants are mediated by the 103-104 molecular weight fraction in Shield lakewater. Can. J. Fish. aquat. Sci. 41: 166-173.

Bratbak, G., 1985. Bacterial biovolume and biomass estimations. Appl. envir. Microbiol. 49: 1488-1493. 
Bratback, H. \& I. Dundas, 1984. Bacterial dry matter content and biomass estimations. Appl. envir. Microbiol. 48: 755757.

Currie, D. J. \& J. Kalff, 1984. The relative importance of bacterioplankton and phytoplankton in phosphorus uptake in freshwater. Limnol. Oceanogr. 29: 311-321.

Deinema, M. H., L. H. A. Habets, J. Scholten, E. Turkstra \& H. A. A. M. Webers, 1980. The accumulation of polyphosphate in Acinetobacter spp. FEMS (Fed. Eur. Microbiol. Soc.) Microbiol. Lett. 9: 275-279.

Einsele, W., 1936. Über die Beziehungen des Eisenkreislaufs zum Phosphatkreislauf im eutrophen See. Arch. Hydrobiol. 29: 664-686.

Einsele, W. \& H. Vetter, 1938. Untersuchungen uber die Entwicklung der physikalischen und chemischen Verhaltnisse im Jahreszyklus in einem mässig eutrophen See (Schleinsee bei Langenargen). Int. Revue ges. Hydrobiol. Hydrogr. 36: 285-324.

Fenchel, T. \& T. H. Blackburn, 1979. Bacteria and mineral cycling. Academic Press, London.

Fleischer, S., 1983. Microbial phosphorus release during enhanced glycolysis. Naturwissenschaften 70: 415-416.

Fleischer, S., 1986. Aerobic uptake of Fe(III)-precipitated phosphorus by microorganisms. Arch. Hydrobiol. 107: 269-277.

Fricker, Hj., 1980. OECD Eutrophication program - Regional Project Alpine Lakes. Swiss Federal Board for Environmental Protection, Bern, Switzerland.

Gächter, R. \& J. Bloesch, 1985. Seasonal and vertical in the $\mathrm{C}: \mathrm{P}$ ratio of suspended and settling seston of lakes. $\mathrm{Hy}-$ drobiologia 128: 193-200.

Gächter, R., 1987. Lake restoration. Why oxygenation and artificial mixing cannot substitute for a decrease in the external phosphorus loading. Schweiz. Z. Hydrol. 49: 170185.

Gächter, R. \& A. Mares, 1985. Does settling seston release soluble reactive phosphorus in the hypolimnion of lakes? Limnol. Oceanogr. 30: 364-371.

Gächter, R., J. S. Meyer \& A. Mares, 1988. Contribution of bacteria to release and fixation of phosphorus in lake sediments. Limnol. Oceanogr. 33: 1542-1558.

Gächter, R., A. Tessier, E. Szabo \& R. Carignan, 1991. Measurements of total dissolved phosphorus in small volumes of iron-rich interstitial water. Aquatic Sciences (in Press).

Hayes, F. R. \& J. E. Phillips, 1958. Lake water and sediment. IV. Radiophosphorus equilibrium with mud, plants, and bacteria under oxidized and reduced conditions. Limnol. Oecanogr. 3: 459-475.

Hoffmeister, D., D. Weltin \& W. Dott, 1990. Untersuchungen zur bakteriellen Phosphatelimninierung. II. Mitteilung: Physiologische Untersuchungen an Reinkulturen. Wasser, Abwasser, gwf. 131: 270-277.

Hupfer, M. \& D. Uhlmann, 1990. Phosphate immobilization by microorganisms in lake sediments. Sediment/Water Interactions $5^{\text {th }}$ International Symposium. August 6-9, 1990. Uppsala.
Hupfer, M. \& D. Uhlmann, 1991. Microbially mediated phosphorus exchange across the mud-water interface. Verh. int. Ver. Limnol. 24: 2999-3003.

Jackson, T. A. \& D. W. Schindler, 1975. The biochemistry of phosphorus in an experimental lake environment: evidence for the formation of humic-metal-phosphate complexes. Verh. int. Ver. Limnol. 19: 211-221.

Jewell, W. L. J. \& P. L. McCarty, 1968. Aerobic decomposition of algae and nutrient regeneration. Stanford Univ. Techn. Rep. 91.

Jones, J. G., M. J. L. G. Orlandi \& B. M. Simon, 1979. A microbiological study of sediments from the Cumbrian lakes. J. Gen. Microbiol. 115: 37-48.

Jordan, M. J., G. E. Likens \& B. J. Peterson, 1985. Organic carbon budget. In: G. E. Likens (ed.). An Ecosystem Approach to Aquatic Ecology. Mirror Lake and its Environment. Springer-Verlag. ISBN 0-387-96106-2.

Kämpfer, P., A. Eisenträger, V. Hergt \& W. Dott, 1990. Untersuchungen zur bakteriellen Phosphatelimninierung. I. Mitteilung: Bakterienflora und bakterielles Phosphatspeicherungsvermögen in Abwasserreinigungsanlagen. Wasser, Abwasser gwf. 131: 156-164.

Kulaev, I. S., 1979. The biochemistry of inorganic polyphosphates. Wiley.

Laczko, E., 1988. Abbau von planktischem Detritus in den Sedimenten voralpiner Seen: Dynamik der beteiligten Mikroorganismen und Kinetik des biokatalysierten Phosphoraustausches. Ph. D. Thesis Nr. 8371, Eidgen 8 ssische Tech. Hochschule (ETH), Zürich, Switzerland.

Lean, D. R. S., 1973a. Phosphorus dynamics in lake water. Science 179: 678-680.

Lean, D. R. S., 1973b. Movements of phosphorus between its biologically important forms in lake water. J. Fish. Res. Bd. Can. 30: 1525-1536.

Lean, D. R. S., 1984. Metabolic indicators for phosphorus limitation. Verh. int. Ver. Limnol. 22: 211-213.

Lean, D. R. S. \& F. H. Rigler, 1974. A test of the hypothesis that abiotic phosphate complexing influences phosphorus kinetics in the epilimnetic lake water. Limnol. Oceanogr. 19: 787-788.

Lean, D. R. S. \& E. White, 1983. Chemical and radiotracer measurements of phosphorus uptake by lake plankton. Can. J. Fish. aquat. Sci. 40: 147-155.

Levine, S. N., 1975. A preliminary investigation of orthophosphate concentration and the uptake of orthophosphate by seston in two Canadian Shield lakes. MS. Thesis, University of Manitoba, pp. 151.

Levine, S. N. \& D. W. Schindler, 1980. Radiochemical analysis of orthophosphate concentrations and seasonal changes in the flux of orthophosphate to seston in two Canadian Shield lakes. Can. J. Fish. aquat. Sci. 37: 479487.

Likens, G. E., 1985. The Lake-Ecosystem. In: G. E. Likens (ed.), An Ecosystem Approach to Aquatic Ecology. Mirror Lake and its Environment. Springer-Verlag. ISBN 0-38796106-2. 
Mortimer, C. H., 1941-1942. The exchange of dissolved substances between mud and water in lakes. 1 and 2.3 and 4 . J. Ecol. 29: 280-329; 30: 147-201.

Mortimer, C. H., 1971. Chemical exchanges between sediments and water in the Great Lakes - speculations and probable regulatory mechanisms. Limnol. Oceanogr. 16: 387-404.

Osgood, R. A., 1988. A hypothesis on the role of Aphanizomenon in translocating phosphorus. Hydrobiologia 169: 6979.

Planas, D., 1978. Phosphorus uptake rates in planktonic communities related to light gradient. Verh. int. Ver. Limnol. 20 : 2731-2736.

Psenner, R., R. Pucsko \& M. Sager, 1984. Die Fraktionierung organischer und anorganischer Phosphorverbindungen von Sedimenten. Arch. Hydrobiol./Suppl. 70: 111-155.

Psenner, R. \& R. Pucsko, 1988. Phosphorus fractionation: advantages and limits of the method for the study of sediment $\mathrm{P}$ origins and interactions. Arch. Hydrobiol. Beih. Ergebn. Limnol. 30: 43-59.

Psenner, R., B. Boström, M. Dinka, K. Pettersson, R, Puckso \& M. Sager, 1988. Sediment phosphorus group: Working group summaries and proposals for future research. 4 . Fractionation of phosphorus in suspended matter and sediment. Arch. Hydrobiol. Beih. Ergebn. Limnol. 30: 98110.

Redfield, A. C., B. H. Ketchum \& F. A. Richards, 1963. The influence of organisms on the composition of sea water. In: M. N. Hill (ed.), The Sea, v. 2. Interscience: 26-77.

Riemann, B. \& R. T. Bell, 1990. Advances in estimating bacterial biomass and growth in aquatic systems; Arch. Hydrobiol. 118: 385-402.

Rigler, F. H., 1973. A dynamic view of the phosphorus cycle in lakes. In: E. J. Griffith, A. Beeton, J. M. Spencer \& D. T. Mitchell (eds), Environmental Phosphorus Handbook. John Wiley \& Sons: 539-572.

Shuter, B. J., 1978. Size dependence of phosphorus and nitrogen subsistence quotas in unicellular microorganisms. Limnol. Oceanogr. 23: 1248-1255.

Sinke, A. J. C. \& T. E. Cappenberg, 1988. Influence of bacterial processes on the phosphorus release from sediments in the eutrophic Loosdrecht Lakes, The Netherlands. Arch. Hydrobiol. Beih. Ergebn. Limnol. 30: 5-13.

Stöckli, A. P., 1985. Die Rolle der Bakterien bei der Regeneration von Nährstoffen aus Algenexkreten und Autolyseprodukten. Experimente mit gekoppelten, kontinuierlichen Kulturen. Ph. D. Thesis Nr. 7850, Eidgenőssische Technische Hochschule (ETH) Zürich. 183 pp.

Uhlmann, D. \& H.-D. Bauer, 1988. A remark on microorganisms in lake sediments with emphasis on polyphosphateaccumulating bacteria. Int. Revue ges. Hydrobiol. 73: 703708 .

Uhlmann, D., I. Röske, M. Hupfer \& G. Ohms, 1990. A simple method to distinguish between polyphosphate and other phosphate fractions of activated sludge. Wat. Res. 24: 1355-1360.

Vladstein, O., A. Jensen, Y. Olsen \& H. Reinertsen, 1988. Growth and phosphorus status of limnetic phytoplankton and bacteria. Limnol. Oceanogr. 33: 489-503.

Van Groenestijn, J. W., 1988. Accumulation and degradation of polyphosphate in Acinetobacter sp. Ph. D. Thesis, Agricultural University, Wageningen, The Netherlands.

Vollenweider, R. A., 1974. A Manual on Methods for Measuring Primary Production in Aquatic Environments. IBP Handbook Nr. 12 ISBN 0-632-00531-9. 225 pp.

Wentzel, M. C., L. H. Lötter, R. E. Loewenthal \& G. V. R. Marais, 1986. Metabolic behaviour of Acinetobacter spp. in enhanced biological phosphorus removal - a biochemical model. Water SA 12: 209-224.

Wetzel, R. G., 1983. Limnology. Second Edition. Saunders College Publishing. ISBN 0-03-057931-9. $767 \mathrm{pp}$.

Williams, J. D. H., 1973. Phosphorus in the sediments of Okanagan mainstem lakes. Supplement report to task 121 report by B. E. St. John entitled 'The limnogeology of the Okanagan mainstem lakes' (not published).

Williams, J. D. H., T. P. Murphy \& T. Mayer, 1976. Rates of accumulation of phosphorus forms in Lake Erie sediments. J. Fish. Res. Bd. Can. 33: 430-439.

Wolf, G., 1986. Die Verteilung des partikulären Phosphors und sein Verhältnis zur Biomasse der Blaualge Oscillatoria limosa im Pelagial des Piburgersees. Diplomarbeit Universität Insbruck. 